JOSING: Journal of Nursing and Health

Volume 2, Nomor 2, Juni 2022

e-ISSN: 2745-7877

p-ISSN: 2746-0851

DOI: https://doi.org/10.31539/josing.v2i2.3440

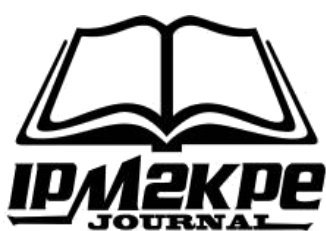

\title{
SELF-EFFICACY AS DETERMINANT OF INTEREST BECOMING INTENSIVE CARE NURSE
}

\author{
Eva Metalita ${ }^{1}$, Hanny Handiyani ${ }^{2}$, Kuntarti $^{3}$, Tuti Afriani ${ }^{4}$, Nurdiana $^{5}$ \\ University of Indonesia $1,2,3,4$ \\ RSUPN Dr. Cipto Mangunkusumo 5 \\ evametalita@gmail.com ${ }^{1}$
}

\begin{abstract}
This study aims to identify the factors that influence interest in becoming an intensive nurse. The design of this study used a cross-sectional approach. The results showed self-efficacy, appreciation, work unit, age, family support and supervisor support $(p=<0.001)$, years of service $(p=0.005)$, gender $(p=0.002)$, career level $(p=0.004)$, and experience. Training $(p=0.003)$ affected the interest of intensive nurses. On the other hand, knowledge and level of education were not influenced by the pull of intensive nurses. The results of multiple linear regression analysis found that the most influential interest factors in becoming an intensive nurse were self-efficacy, followed by rewards, work units, and gender. These four factors contributed $57.4 \%$ in influencing the interest in becoming an intensive nurse. In conclusion, what most determines interest in becoming an intensive nurse is self-efficacy.
\end{abstract}

Keywords: Determinants, Interests, ICU Nurse

\section{INTRODUCTION}

The interest in becoming an intensive nurse is the desire to choose a career in the intensive unit area. It needs to be evaluated by nursing managers to meet the increasingly high demand for intensive care nurses worldwide. The increase of nurses required in the intensive care unit is due to the increasing need for beds, impacting the limited number of officers needed in the intensive unit (Paneru, 2020). Bambi et al., (2020) declared that preparation is required to fill positions as intensive nurses by training nurses in non-intensive units to be placed in intensive care units, along with the increasing need for intensive nurses.

Nurses' satisfaction with their work is closely related to their work suitability with interests. When nurses choose their preferred career workplace, they will have the desire, hope and be more effective at work. Job satisfaction is positively related to interests suitability and conversely. Job satisfaction also experiences significant changes to feelings of interest (Nye et al., 2020). Generally, interests are closely related to performance outcomes and career path satisfaction (Hoff et al., 2020).

There are several advantages when placing nurses according to their area of interest. Thus, nursing managers need to pay attention to it when placing them in the intensive unit so that they are willing to be recognized when intensive nurses need to increase. Interest can influence nurses to be ready to be placed in a work environment that suits their desires. Besides, they can decide on the preferred workplace according to their interests (Elibol \& Seren, 2017). Nurses' willingness to be placed is closely related 
to their interests. Thus, managers need to pay attention to interest when recruiting or rotating (Chi et al., 2018).

The nurse's interest in choosing the workplace to be undertaken has various reasons that can be sourced from internal or external. Nurses' topics regarding the desire to plan a career as an intensive nurse were personal desire, knowledge of nursing problems, self-efficacy, skills and special preparation in specialist areas, and social support. Meanwhile, the lack of reward and the difference in financial income becomes why they do not want to have a career as an intensive nurse (Chang et al., 2018., Liaw et al., 2017). Thus, well-facilitated nurse career development and hospital leadership support can increase nurses' desire to endure working in hospitals (Nurdiana et al., 2019).

The low interest in becoming an intensive nurse can make nurses want to leave their jobs and bring losses to the organization, especially those who have attended the training. The National Health Service survey showed that the critical nursing area had the highest number of nurses leaving their work than nurses in other units, i.e. $5 \%$ to 27\% (Khan et al., 2019). Furthermore, research in Pennsylvania, United States, states as many as $20 \%$ of nurses in intensive care units dislike their work and plan to leave (Smith et al., 2020).

Previous research in one of the national referral hospitals in Jakarta indicated an interest in being an intensive nurse for nurses with PK II level showed the results were quite interesting, i.e. 63.3\% (Metalita et al., 2021). In a preliminary study at Hospital X South Kalimantan, based on unstructured interviews with the head of the nursing workplace, there were difficulties in recruiting nurses to be willing to be placed in the intensive unit. Furthermore, the interview with eight nurses showed that eight nurses stated they were less interested in being intensive nurses. By looking this phenomenon and there is a lack of literature about factor influencing nurse interest becoming intensive care nurse, the author would like to identify interest determinants to become an intensive nurse.

\section{RESEARCH METHOD}

This study used a descriptive correlation research design with a cross-sectional approach. The sample of this study consisted of 188 nurses with inclusion criteria in all implementing nurses who served in inpatient units, ICU and IGD with education levels of D3 Nursing and S.Kep Nurses, at the career level PK I to PK III willing participate as respondents in the research.

The writer upholds ethical principles, including respecting respondent dignity, maintaining personal confidentiality, providing justice and considering the impact. This study was conducted after obtaining an ethical review certificate from FIK UI with the Number of Ket 253/UN2.F12.D1.2.1/PPM.00.02/2021 and a letter of passing the ethics test from Idaman Hospital Banjarbaru City with No.018/KEPK-RSDI/ X/2021. Furthermore, the data collection process was carried out after obtaining permission and passed the ethical review from the hospital. Then, data collection is conducted using a google form head of the room assistant.

The research instrument was obtained through a questionnaire to measure interest to become intensive nurse, self-efficacy, appreciation, family support, and supervisor support consisting of 60 statements by measuring using a Likert scale (1-5). Meanwhile, knowledge consisted of 9 multiple choice questions with a 0-100 score range. The interest questionnaire to become an intensive nurse was modified from the Individual 
and Situational Interest questionnaire by Rotgans \& Schmidt. The knowledge questionnaire used the Intensive Nurse Knowledge questionnaire by Dominique Vandijk et al. The uni-dimensional self-efficacy questionnaire was modified from the General Self questionnaire by Zhou. Meanwhile, the reward questionnaire was modified from the financial and non-financial reward questionnaire by Hains.

The family support questionnaire consisted of emotional and instrumental support changed from the perceived family support questionnaire and the supervisor support questionnaire consists of emotional and instrumental support modified from the perceived supervisor support questionnaire by Boyar. The validity test results of all the questions on the questionnaire ranged from 0.472 to 0.933 , and the reliability value was $>$ 0.7. Furthermore, the data analysis was conducted using univariate (mean/median, $\mathrm{SD}$, min-max, 95\% CI for numerical data and frequency and proportion for categorical data) and multivariate analysis using multiple linear regression.

\section{RESULTS}

Table. 1

Distribution of Characteristics of Gender, Education Level, Work Units, PK Level, and Training $(\mathrm{n}=188)$

\begin{tabular}{lcc}
\hline \multicolumn{1}{c}{ Variable } & Jumlah \\
& $\mathrm{n}$ & $\%$ \\
\hline Gender & 88 & 46,8 \\
a. Male & 100 & 53,2 \\
b. Female & 102 & 54,3 \\
\hline Level of Education & 86 & 45,7 \\
a. Nursing Diploma & & \\
b. Bachelor of Nursing (Ners) & 112 & 59,6 \\
\hline Work Unit & 20 & 10,6 \\
a. Medical surgical ward & 56 & 29,8 \\
b. Emergency room & & \\
c. Intensive care unit (ICU, HCU, ICCU, PICU, NICU, & \\
$\quad$ ICU Covid) & & \\
\hline Clinical Nurse Level & 108 & 57,4 \\
a. PK I & 42 & 22,3 \\
b. PK II & 38 & 20,2 \\
c. PK III & & \\
\hline Trainning & 20 & 10,6 \\
a. None & 114 & 60,6 \\
b. BLS & 4 & 2,1 \\
c. ALS & 22 & 11,7 \\
d. ICU trainning & 29 & 14,9 \\
e. Other & & \\
\hline
\end{tabular}

Based on the univariate analysis results related to nurses characteristics shown on table 1, most nurses were female (53.2\%). Whereas 54.3\% had D3 nursing education, $59.6 \%$ came from the inpatient work unit, 57.4\% from PK level I, and $60.6 \%$ had attended BLS training. The average age of nurses was 30 years and had four years working period. 
Table. 2

Distribution of Nurses Based on Interest in Becoming an Intensive Nurse $(\mathrm{n}=188)$

\begin{tabular}{lccc}
\hline Variable & Mean \pm SD & $95 \%$ CI & $\% *$ \\
\hline Interest & $41,25 \pm 10,68$ & $39,71-42,79$ & 60,93 \\
Individual interest & $24,34 \pm 6,35$ & $23,42-25,25$ & 61,92 \\
Situasional interest & $16,91 \pm 4,69$ & $16,23-7,59$ & 59,55 \\
\hline
\end{tabular}

Table 2 shown, the nurses' interest analysis results showed that the mean score of interest in being an intensive nurse was $41.25 \pm 10.68$, with a mean score of individual interest $24.34 \pm 6.35$ and situational interest $16.91 \pm 4.69$. If converted in the range $0-100$, the score was $60.93 \%$ in a row, $61.92 \%$, and $59.55 \%$. The mean individual interest score was more significant than the mean score of situational interest.

Table. 3

Distribution of Nurses Based on Knowledge, Self-Efficacy, Rewards, Family Support and Superior Support $(n=188)$

\begin{tabular}{lccc}
\hline Variable & Mean \pm SD & $95 \%$ CI & $\%$ \\
\hline Knowledge & $68,01 \pm 36,18$ & $62,81-73,22$ & \\
Self Efficacy & $45,12 \pm 6,92$ & $44,13-46,12$ & 69,00 \\
Reward & $45,7 \pm 7,87$ & $44,58-46,84$ & 70,20 \\
$\quad$ Financial Reward & $20 \pm 3,41$ & $19,64-20,62$ & 75 \\
$\quad$ Non financial Reward & $25,5 \pm 5,16$ & $24,83-26,31$ & 66,07 \\
Family Support & $44,75 \pm 7,92$ & $43,61-45,89$ & 68,22 \\
$\quad$ Emotional Support & $23,05 \pm 3,99$ & $22,47-23,62$ & 71,04 \\
$\quad$ Instrumental Support & $21,70 \pm 4,32$ & $21,07-22,32$ & 65,41 \\
Supervisor Support & $45,38 \pm 7,79$ & $44,26-46,50$ & 69,54 \\
$\quad$ Emotional Support & $22,79 \pm 3,95$ & $22,22-23,36$ & 56,39 \\
$\quad$ Instrumental Support & $22,58 \pm 3,93$ & $22,01-23,15$ & 87,90 \\
\hline
\end{tabular}

Based on table 3, it can be seen that the mean score of nurses' knowledge was $68.01 \pm 36.18$, nurses' self-efficacy was $45.12 \pm 6.92$, the rewards received by the nurse

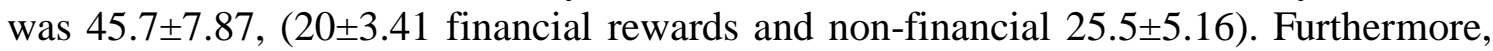
the mean of family support was $44.75 \pm 7.92$ (emotional support $23.05 \pm 3.99$ and instrumental support 21.70 \pm 4.32 ). The mean superior support was $45.38 \pm 7.79$ (emotional supervisor support $22.79 \pm 3.95$ and instrumental support 22.58 \pm 3.93 ). If converted into a value of 0-100, the knowledge value was 68.01 , self-efficacy was $69 \%$, the reward was $70.20 \%$ (75\% financial and non-financial $66.07 \%$ ), family support was $68.22 \%$ (emotional $71.04 \%$ and instrumental $65.41 \%$ ), and support from superiors (emotional 56.39\% and instrumental 87.90\%).

Table 4.

Multivariate Analysis Model

\begin{tabular}{lcccc}
\hline Model & $\beta$ & Standar Error & $t$ & Sign. \\
\hline Constant: 1,478 & & & 0,275 & 0,121 \\
Work unit & 0,257 & 0,604 & 5,056 & $<0,001$ \\
Gender & 0,136 & 1,068 & 2,727 & 0,007 \\
Self efficacy & 0,381 & 0,096 & 4,621 & $<0,001$ \\
Reward & 0,282 & 0,083 & 4,720 & $<0,001$ \\
\hline
\end{tabular}


The results of the study indicated that the variables qualified for the candidate's selection in multivariate analysis were age $(p=<0.001)$, gender $(p=0.002)$, years of working $(\mathrm{p}=0.005)$, work unit $(\mathrm{p}=0.001)$, PK level $(\mathrm{p}=0.004)$, training $(\mathrm{p}=0.003)$, selfefficacy $(\mathrm{p}=<0.001)$, rewards $(\mathrm{p}=<0.001)$, family support $(\mathrm{p}=<0.001)$, and supervisor support $(\mathrm{p}=<0.001)$. Meanwhile, the level of education $(\mathrm{p}=0.262)$ and knowledge $(\mathrm{p}=$ 0.479 ) did not relate to an interest in being an intensive nurse. After knowing several independent variables did not affect the interest in becoming an intensive nurse, the regression test was obtained using the backward method. It could gradually remove the variable with the highest $\mathrm{p}$-value. The results obtained showed that gender, work unit, self-efficacy and appreciation variables influenced interest in becoming an intensive nurse. The variables that meet the regression analysis are gender, work unit, selfefficacy and appreciation. The final modelling of the multivariate analysis showed that the factors that most influenced interest in becoming an intensive nurse were selfefficacy with a value of 0.381 followed by an reward of 0.282 , a work unit of 0.257 and gender 0.136 .

\section{DISCUSSION \\ Interest}

The overall interest of nurses is only in the moderate interest category. Thus, it still needs to be improved. Interests consist of individual interests or interests within the nurse itself and situational interests from external factors. Hence, the efforts still need to increase interest. Situational interest is usually temporary and occurs because of the external environment influence (Rotgans \& Schmidt, 2018). Individual and situational interests influence and benefit the organization, especially workforce management related to nursing placement and work productivity (Kuvaas et al., 2017; Turner, 2017).

The sub-variable of individual interest by nurses is more significant than situational interest. It means that interest comes from within (intrinsic) and can reflect placing nurses in the intensive unit. The arrangement of intensive nurses according to interests will give advantages to the organization because it affects job satisfaction, increased motivation, and nurse retention. Thus, it can impact the quality of the service provided. People who work according to their interests tend to get job satisfaction (Hoff et al., 2020). Besides, Individual interests are a reference to the interest to determine the profession or field of work to be chosen (Liaw et al., 2017).

The sub-variable of situational interest or interest in being an intensive nurse occurs because of the supporting factors from the external environment. That external environment influences each other with an individual interest in the nurse's decision to choose a career. Situational interest influences a person's attitude in choosing his career workplace (Palmer et al., 2017). Factors that foster extrinsic interest affect the workforce because they can help adequately utilize staff skills. Hence, they are willing to be placed in the appropriate job workplace (Turner, 2017). Situational interest depends on external environmental factors. Thus, the optimization of extrinsic supporting factors will affect the interest in choosing a career as an intensive nurse.

\section{Knowledge}

Nurses' knowledge of intensive care services, including patient safety and service quality, is in the sufficient category. They need a basic understanding of patient care and safety knowledge (Okumura et al., 2019). Nurses who work in intensive units must have that knowledge with critical health situations that require complex individual 
interventions to meet patient needs (Khalil, 2019). The knowledge is advanced, requires special preparation, and is highly valued. Thus, it becomes a challenge and difficulty when nurses become intensive nurses.

There is no relationship between knowledge and interest in being an intensive nurse. However, there is a tendency, the higher the basic knowledge of nurses on services in the intensive unit, the lower the interest of nurses. Otherwise, the knowledge can result in boredom and loss of interest. Thus, it can make nurses more aware of the duties and responsibilities of intensive nurses, which are pretty significant in caring for critical patients, resulting in reduced nurses' interest Fastrich \& Murayama (2020) stated no significant relationship between the individual, situational interests and knowledge, high knowledge can increase individual interest situational interest and reduce feelings of interest.

Nurses' knowledge related to services in the intensive unit is not the basis for nurses' desire to become intensive nurses. Collins et al., (2018) state that there is no relationship between knowledge of the workplace and interest in the workplace. It means that the common knowledge of nurses does not become the basis for nurses not being interested in becoming intensive nurses. Contrarily, high knowledge does not affect the desire to become intensive nurses.

\section{Self Efficacy}

A nurse's self-efficacy will allow the nurse to carry out her responsibilities according to her passion so that they can be confident in making decisions about choosing the workplace that suits their desires. The most determined interest factor in being an intensive nurse is self-efficacy. Every one increase in self-efficacy scores will increase interest by 0.381 . Confidence in making decisions about workplace choices can be seen from the trust to assess the ability to solve problems related to career selection (Dharma \& Akmal, 2019). Self-efficacy is a determining factor influencing to interest and decision making of nurse in workplace. It means that the better the nurses' selfefficacy, the greater their interest in choosing a career as a nurse in the intensive unit (Su et al., 2021).

This study showed that nurses have self-efficacy to become intensive nurses. However, nurses' self-efficacy is still at different levels. The phenomenon that occurs nowadays is nurses' self-efficacy is not balanced because some of them have low selfefficacy, and some have high self-efficacy (Kurnia et al., 2019). Their self-efficacy positively influences career interest in nurses. At the same time, the lack of ability is the main obstacle for nurses to choose a career in a specialist area (Huang et al., 2019). Self-efficacy can change dynamically due to new experiences, increased knowledge and skills. Thus, follow-up efforts are needed to maintain and improve self-efficacy.

Efforts to increase nurses self-efficacy can make their interest in becoming intensive nurses. One of the strategies is improving the abilities and skills of nurses by participating in workshops and training. Research found a significant relationship between training and increased nurses self-efficacy working in intensive units (Murphy et al., 2019).

Nurses' self-efficacy can be maintained and increased through various efforts that require support from hospitals and nurse managers. According to Ageiz et al., (2021) nurse managers can strengthen nurses' beliefs about their abilities to influence nurses' interest in choosing jobs and making decisions. High nurse self-efficacy, managers can be a driving force to increase nurses' self-efficacy through being a role model or 
providing verbal encouragement (Fida et al., 2018). It can be concluded the role of hospital management is needed in seeking to increase the self-efficacy of nurses so that they are interested in becoming intensive nurses.

\section{Reward}

Reward are bonuses for nurses to motivate performance, encourage interest and influence decision-making to choose the workplace. According to Nur et al., (2018) reward can be financial or non-financial such as giving recognition. Rewards are important in determining performance and are positively related to interest and motivation (Nursalam et al., 2019). The reward for intensive nurses can be increased based on standards by considering the workload, work risk, work stress and nurse skills.

There is a relationship between appreciation and interest in being an intensive nurse. The reward can influence the nurse's desire to choose a workplace in a specialist area of the intensive unit. Furthermore, the reward given to intensive nurses is a form of commitment from the agency to meet the nurses need to increase the motivation and interest. This is in line with (Samuel \& Abdulkarim, 2019) research, which states that staff become more interested and motivated in their job with rewards. Other research shows rewards and benefits on the interest in nurses' role in the intensive unit (Macey et al., 2021). Based on PMK 40 of 2017, developing a clinical nurse career path is a form of appreciation for intensive nurses. It allows them to build their careers to the peak level of competence, i.e. PK 5 if they have specialist qualifications.

The results showed that the sub-variables of financial rewards' sub-variables were greater than non-financial rewards and influenced their interest in becoming intensive nurses. Financial rewards in the form of salaries, bonuses, and incentives received further increase the desire to become an intensive nurse because of the higher workload and work stress level than working in a non-intensive unit. It follows the research of Hains (2018) which states that wages related to finance will affect the motivation and interest of nurses in the workplace. The increasing income through salaries and incentives supports can increase job satisfaction and giving impact to interest of workplace among nurse (Akinwale \& George, 2020). The more significant the income received by an intensive nurse, the more nurse will receive welfare from their work so that interest in the workplace will be higher.

\section{Family Support}

Nurses receive support from their families to become intensive nurses in emotional and instrumental support. Support provided by the family can encourage a nurse's desire to choose a workplace as an intensive nurse. Family support is the primary source of social support, which influences career interests and decision-making in choosing a career (Xing \& Rojewski, 2018). Support from family makes nurses have a stronger desire for their career interests (Yoon, 2020).

The results showed family support and interest in being an intensive nurse. Family support to become an intensive nurse can balance the demands of work and the responsibilities of carrying out roles in the family so that there is no conflict between work-family. Nurses need support from families regarding multifunctional parts of life and the clinical role of nurses. Family support can influence interest to nurse career choices (Sari, 2020). The relationship between support from the family and the nurse's interest in choosing a career is in line with research by Leung et al., (2020) that the most 
crucial support from the family to maintain a career balance and the desire to choose a career is in the form of emotional support as well as instrumental support.

The sub-variable of family emotional support received by nurses is more significant than instrumental support in influencing interest in becoming an intensive nurse. The form of family emotional support is by helping nurses decide on career choices according to their interests, giving confidence in their ability to become intensive nurses and listening to nurses' wishes for their careers. This is in line with research conducted by, which states that family support can influence nurses' interest job satisfaction (Gonnelli et al., 2018). Family support provided by the family will convince nurses to help make decisions about choosing a career (Koçak et al., 2021). The family is the closest person to the nurse, so the emotional support provided will have a psychological impact on them and affect their interest in becoming an intensive nurse.

\section{Supervisor Support}

This study shows that nurses argue getting support from their supervisors to choose and develop careers according to their interests to become intensive nurses. Supervisors support is the primary support that can stimulate the motivation and interest of nurses in the workplace. Career development and staff interest require support from supervisors, which is manifested in encouragement and motivation (Adams et al., 2019). The head of the room needs to set a career path based on the performance, skills, expertise and interests of the implementing nurse to have the appropriate career path (Rayatin, 2018).

There is a relationship between supervisor support and interest in becoming an intensive nurse by the instrumental supervisor support sub-variable being greater than emotional support. Emotional and instrumental support related to work from supervisors and agencies was negatively related to intention to quit work and positively associated with interest and job satisfaction (Khan et al., 2020). Supervisors can help foster a nurse's sense of interest and interest in a workplace, thereby creating a desire to choose a career in that line of work (Putra \& Supadmi, 2019). It shows that nurses perceive that support from supervisors can influence their interest and desire to become intensive nurses.

The instrumental supervisor support sub-variable in concrete or real support obtained more significant results than the emotional support sub-variable and affected interest in becoming an intensive nurse. Instrumental support is in the form of opportunities to choose a career as an intensive nurse, providing needs and facilities that support career choices, reducing workload and being fair by placing nurses according to their interests. Support in the simple form by supervisors, one of which is human resources arrangements should consider when developing strategies to improve nurse retention, reduce nurses' workload and increase the interest of nurses to work in the intensive care unit (Khan et al., 2019). Nurses tend to need instrumental support in the form of availability of resources to facilitate their needs so that they are interested and make career choices in the workplace as intensive nurses.

\section{CONCLUSION}

The results indicated the average respondent was 30 years old and had a working period of 4 years. Most of the respondents were female, with a D3 nursing education level, coming from an inpatient work unit. Besides having a PK I level, having attended 
basic life support training, and being a nurse. On the other hand, intensive is in the lacking category. Thus, it needs improvement.

Diversity of age, gender, work unit, years of service, level of PK, and training affect interest in becoming an intensive nurse. Interest in becoming an intensive nurse at a hospital is not influenced by education and knowledge. However, it is influenced by several factors, namely self-efficacy, reward, supervisor support and family support. Support from supervisor and family is important to provide facilities to maintain career balance and career choice decisions so that there is no family-work conflict. Hospitals must ensure that the number of intensive nurses needs is sufficient so that the workload of intensive nurses is not too high. The results of this study can also be used as a reference for hospitals to take policies to increase interest in being intensive nurses. For example, providing remuneration according to workload, providing opportunities to improve career paths, and providing knowledge and information for nurses related to intensive units by considering various factors and adjusting to conditions of the environment, characteristics, and psychology of nurses.

This study indicated that self-efficacy is the most influential interest factor in becoming an intensive nurse. Hospital management can make efforts to maintain and improve nurses' self-efficacy.

\section{SUGGESTIONS}

Hospital management is expected to facilitate conducting training, especially training programs for competency development and soft skills related to critical/intensive nursing areas for nurses on an ongoing basis to improve their skills and abilities. Thus, they are interested in becoming intensive nurses. The condition of the work environment and the completeness of adequate service facilities in the intensive unit must also be as consideration for hospital management so that nurses are interested in working as intensive nurses.

\section{REFERENCES}

Adams, A. M. N., Chamberlain, D., \& Giles, T. M. (2019). The Perceived and Experienced Role of the Nurse Unit Manager in Supporting the Wellbeing of Intensive Care Unit Nurses: An Integrative Literature Review. Australian Critical Care, 32(4), 319-329. https://doi.org/10.1016/j.aucc.2018.06.003

Ageiz, M. H., Ebrahem, S. M., Abo-Shereda, H. M. (2021). Nurse Manager's Meaningful Recognition Program: Its Relation to Staff Nurses' Sense of Coherence and Self-Efficacy during COVID-19 Pandemic. Systematic Reviews in Pharmacy, 12(1), 1219-1229. https://doi.org/10.31838/srp.2021.2.72

Akinwale, E. M., \& George, O. J. (2020). Work Environment and Job Satisfaction Among Nurses in Government Tertiary Hospitals in Nigeria. Rajagiri Management Journal, 14(1), 71-92. DOI: 10.1108/ramj-01-2020-0002

Bambi S., Iozzo P., \& Lucchini, A. (2020). New Issues In Nursing Management During The Covid-19 Pandemic In Italy. American Journal of Critical Care, 29(4), e92e93. DOI: $10.4037 /$ ajcc2020937

Chang, H. Y., Friesner, D., Chu, T. L., Huang, T. L., Liao, Y. N., \& Teng, C. I. (2018). The Impact of Burnout on Self-Efficacy, Outcome Expectations, Career Interest and Nurse Turnover. Journal of Advanced Nursing, 74(11), 2555-2565. DOI: $10.1111 /$ jan. 13776 
Chi, H., Yeh, H., \& Guo, T. (2018). Salary or Job Interest? How Salary and Job Interest Moderates the Willingness to Apply for a Job. Asia-Pacific Journal of Business Administration, 10(1), 64-78. https://doi.org/10.1108/APJBA-09-2017-0086

Collins, M., Minobe, S., Barreiro, M., Bordoni, S., Kaspi, Y., Kuwano-Yoshida, A., Keenlyside, N., Manzini, E., O'Reilly, C. H., Sutton, R., Xie, S., \& Zolina, O. (2018). Challenges and opportunities for improved understanding of regional climate dynamics. Nature Clim Change 8, 101-108 (2018). https://doi.org/10.1038/s41558-017-0059-8

Dharma, G., \& Akmal, S. Z. (2019). Career Decision Making Self-Efficacy dan Career Indecision pada Mahasiswa Tingkat Akhir. Seurune Jurnal Psikologi Unsyiah, 2(2), 1-19. https://doi.org/10.24815/s-jpu.v2i2.14203

Elibol, E., \& Seren, A. K. H. (2017). Reasons Nursing Students Choose the Nursing Profession and Their Nursing Image Perceptions: A Survey Study. Nursing Practice Today, 4(2), 67-78. https://npt.tums.ac.ir/index.php/npt/article/view/187

Fastrich, G. M., \& Murayama, K. (2020). Development of Interest and Role of Choice During Sequential Knowledge Acquisition. AERA Open, 6(2), 233285842092998. https://doi.org/10.1177/2332858420929981

Fida, R., Laschinger, H. K. S., \& Leiter, M. P. (2018). The Protective Role of SelfEfficacy Against Workplace Incivility and Burnout in Nursing: A Time-Lagged Study. Health Care Management Review, 43(1), 21-29. https://doi.org/10.1097/HMR.0000000000000126

Gonnelli, C., Agus, M., \& Raffagnino, R. (2018). Work-Family Conflict in Nursing: The Role of Work Schedules, Familial Antecedents and Emotional Regulation. Open Journal of Medical Psychology, 07(04), 123-147. https://doi.org/10.4236/ojmp.2018.74010

Hains, V. V. (2018). Employee Perception of Financial and Non-financial Reward as Elements of Job Performance Evaluation. International Journal of Business and Administrative Studies, 4(2), 53-59. https://doi.org/10.20469/ijbas.4.10002-2

Hoff, K. A., Song, Q. C., Wee, C. J. M., Phan, W. M. J., \& Rounds, J. (2020). Interest Fit and Job Satisfaction: A Systematic Review and Meta-Analysis. Journal of Vocational Behavior, 123(December). https://doi.org/10.1016/j.jvb.2020.103503

Huang, T. L., Friesner, D., Ho, L. H., Yeh, S. L., Lai, C. L., \& Teng, C. I. (2019). Relationship among Upgrades in Academic Qualifications, Practice Accreditations, Self-Efficacy, Outcome Expectations and Nurses' Career Interest. Journal of Nursing Management, 2030(June 2019), 461-470. https://doi.org/10.1111/jonm.12915

Khalil, N. S. (2019). Critical Care Nurses' Knowledge and Practices Concerning Eye Care of Patients at Two Teaching University Hospitals, Egypt. Nursing \& Healthcare International Journal, 3(3). https://doi.org/10.23880/nhij-16000188

Khan, M. I., Shah, S. H. A., Haider, A., Aziz, S., \& Kazmi, M. (2020). The Role of Supervisor Support on Work-Family Conflict and Employee Turnover Intentions in the Workplace With Mediating Effect of Affective Commitment in Twin Cities in the Banking Industry, Pakistan. International Review of Management and Marketing, 10(6), 42-50. https://doi.org/10.32479/irmm.10807

Khan, N., Jackson, D., Stayt, L., \& Walthall, H. (2019). Factors Influencing Nurses' Intentions to Leave Adult Critical Care Settings. Nursing in Critical Care, 24(1), 24-32. https://doi.org/10.1111/nicc.12348 
Koçak, O., Ak, N., Erdem, S. S., Sinan, M., Younis, M. Z., \& Erdoğan, A. (2021). The Role of Family Influence and Academic Satisfaction on Career Decision-Making Self-Efficacy and Happiness. International Journal of Environmental Research and Public Health, 18(11). https://doi.org/10.3390/ijerph18115919

Kurnia, T. A., Trisyani, Y., \& Prawesti, A. (2019). Factors Associated with Nurses' Self-Efficacy in Applying Palliative Care in Intensive Care Unit. Jurnal Ners, 13(2), 219. https://doi.org/10.20473/jn.v13i2.9986

Kuvaas, B., Buch, R., Weibel, A., Dysvik, A., \& Nerstad, C. G. L. (2017). Do Intrinsic and Extrinsic Motivation Relate Differently to Employee Outcomes? Journal of Economic Psychology, 61, 244-258. https://doi.org/10.1016/j.joep.2017.05.004

Leung, Y. K., Mukerjee, J., \& Thurik, R. (2020). The Role of Family Support in WorkFamily Balance and Subjective Well-Being of SME Owners. Journal of Small Business Management, 58(1), 130-163. https://doi.org/10.1080/00472778.2019.1659675

Liaw, S. Y., Wu, L. T., Lopez, V., Chow, Y. L., Lim, S., Holroyd, E., Tan, K. K., \& Wang, W. (2017). Development and Psychometric Testing of an Instrument to Compare Career Choice Influences and Perceptions of Nursing Among Healthcare Students. BMC Medical Education, 17(1). https://doi.org/DOI:10.1186/s12909017-0910-7

Macey, A., Green, C., \& Jarden, R. J. (2021). ICU Nurse Preceptors' Perceptions of Benefits, Rewards, Supports and Commitment to the Preceptor Role: A MixedMethods Study. Nurse Education in Practice, 51(December 2019), 102995. https://doi.org/10.1016/j.nepr.2021.102995

Metalita, E., Handiyani, H., Afriani, T., \& Rayatin, L. (2021). Analisis Jenjang Karir dan Minat Menjadi Perawat Intensif. Jurnal Keperawatan Silampari, 5(1), 156167. https://doi.org/10.31539/jks.v5i1.2907

Murphy, B. M., Higgins, R. O., Le Grande, M., Beauchamp, A., Worcester, M. U., Goble, A. J., \& Jackson, A. C. (2019). Impact of Intensive Training on Health Professionals' Self-Efficacy in Establishing, Running and Maintaining a Cardiac Rehabilitation Program. Journal of Nursing Education and Practice, 9(7), 67. https://doi.org/10.5430/jnep.v9n7p67

Nur, S., Noor, A. M., Nadzirah, S., Zainordin, H. (2018). The Impact of Rewards as Motivation on Job Satisfaction In A Quantity Surveying Consultant Firm. International Journal of Modern Trends in Social Sciences, 1(4), 1-14. https://www.researchgate.net/publication/329809782

Nurdiana, N., Hariyati, R. T. S., \& Gayatri, D. (2019). Head Nurse Strategy for Increasing Nurse Retention: A Factor Analysis. Enfermeria Clinica, 29, 560-566. https://doi.org/10.1016/j.enfcli.2019.04.087

Nursalam, N., Saputri, B. Y., Kartini, Y., \& Sukartini, T. (2019). Analysis of Factors on Reward System in the Hospital. Indian Journal of Public Health Research and Development, 10(1), 490-494. https://doi.org/10.5958/0976-5506.2019.00096.2

Nye, C. D., Wille, B., Amory, J., \& Fruyt, F. D. (2020). Are Work Activities Related to Interest Change Over Time? A 22-Year Longitudinal Study. Journal of Personality and Social Psychology, 121(4), 865-893. DOI: 10.1037/pspp0000360

Okumura, M., Ishigaki, T., Mori, K., \& Fujiwara, Y. (2019). Development of An Easyto-Use Questionnaire Assessing Critical Care Nursing Competence in Japan: A Cross-Sectional study. PLoS ONE, 14(11), 1-11. https://doi.org/10.1371/journal.pone.0225668 
Palmer, D., Dixon, J., \& Archer, J. (2017). Using Situational Interest to Enhance Individual Interest and Science-Related Behaviours. Research in Science Education, 47(4), 731-753. https://doi.org/10.1007/s11165-016-9526-x

Paneru, H. (2020). Intensive Care Units in the Context of Covid-19 in Nepal: Current Status and Need of the Hour. Journal of Society of Anesthesiologists of Nepal, 7(1 SE-View Point), 10-12. https://www.jsan.org.np/jsan/index.php/jsan/article/view/291

Putra, I. B. P. P., \& Supadmi, N. L. (2019). Pengaruh Pelatihan Pasar Modal, Persepsi Mahasiswa, Modal Minimal dan Hubungan Pertemanan pada Minat Berinvestasi. E-Jurnal Akuntansi, 27(2), 1144-1170. https://doi.org/10.24843/EJA.2019.v27.i02.p12

Rayatin, L. (2018). Model Kepemimpinan Servant Paling Dominan Berhubungan dengan Kinerja. JKI Jurnal Keperawatan Indonesia, 21(3), 180-188. https://doi.org/10.7454/jki.v21i3.773

Rotgans, J. I., \& Schmidt, H. G. (2018). How Individual Interest Influences Situational Interest and How Both are Related to Knowledge Acquisition: A Microanalytical Investigation. Journal of Educational Research, 111(5), 530-540. https://doi.org/10.1080/00220671.2017.1310710

Samuel, M. P., \& Abdulkarim, B. (2019). The Impact of Financial and Non-Financial Rewards on Employee Motivation: Case Study NRA Sierra Leone. International Journal of Business, 6(5), 32-34. https://www.ijrbsm.org/papers/v6-i5/4.pdf

Sari, N. P. W. P. (2020). Career Choices among Nursing Students: Differences between Freshmen and Interns. Jurnal Pendidikan Keperawatan Indonesia, 6(1), 1-13. https://doi.org/10.17509/jpki.v6i1.18758

Smith, J. G., Rogowski, J. A., \& Lake, E. T. (2020). Missed Care Relates to Nurse Job Enjoyment and Intention to Leave in Neonatal Intensive Care. Journal of Nursing Management, 28(8), 1940-1947. https://doi.org/10.1111/jonm.12943

Su, X., Wang, W., Li, C., Lang, H., Ni, C., Hu, S., Shao, P., \& Wang, J. (2021). Social Support as a Moderator Between Career Decision Making Self-Efficacy, Professional Commitment and Mental Health: A Structural Equation Modeling Approach. Psychology and Behavioral Science, 17(2), 1-8. https://doi.org/10.19080/PBSIJ.2021.17.555958

Turner, A. (2017). How Does Intrinsic and Extrinsic Motivation Drive Performance Culture in Organizations? Cogent Education, 4(1), 1-5. https://doi.org/10.1080/2331186X.2017.1337543

Xing, X., \& Rojewski, J. (2018). Family Influences on Career Decision-Making SelfEfficacy of Chinese Secondary Vocational Students. New Waves-Educational Research and Development Journal, 21(1), 48-67. https://eric.ed.gov/?id=EJ1211290

Yoon, S. J. (2020). The Factors Affecting on Turnover Intention of Nurses. MedicoLegal Update, 20(1), 1827-1832. https://doi.org/10.37506/v20/il/2020/mlu/194569 